\section{Watching the rivers blow}

\author{
Vera Rich looks at a USSR river diversion \\ project which may use nuclear explosions
}

\begin{abstract}
A RECENT resolution of the Central A Committee of the Communist Party of the Soviet Union and the Council of Ministers on the need for a more rational use of water resources focuses attention once again on one of the most grandiose projects ever proposed by Soviet civil engineers-the diversion of water from the Siberian rivers flowing into the Arctic in order to augment the shrinking resources of the Caspian basin. The growing demands on Soviet agriculture after a series of disastrous harvests and the falling levels of the Caspian and Aral Seas make an injection of new water supplies into this region a prime necessity if the reclaimed virgin lands are not to return to desert and the inland seas are not to become saltmarshes. Accordingly, the final section of the resolution calls for engineering and environmental studies on the practical measures and possible ecological consequences such a plan would entail.
\end{abstract}

Massive hydroengineering projects are by no means new in Russia. Peter I (the Great) proposed to link the Volga and the Don via their tributaries, the Kamyshin and the Lavla, by a navigation canal; he was thwarted by the local governor, Prince Galitsin, who maintained that "God had made the rivers to go one way and it was presumptious in man to think to turn them in another". Peter's daughter, the Tsaritsa Elizabeth, inaugurated a project to link her country retreat of Tsarskoe Selo to St Petersburg by canal, a scheme which was abandoned half-completed when she died in 1762. The most memorable achievement of the Tsarist era involving water concerned not irrigation but drainage-the reclamation of the Neva marshes and the construction, on this unpromising site, of the new capital of St Petersburg. Indeed, the era left no hydroengineering works comparable with its last great engineering triumph, the Trans-Siberian Railway.

The new Soviet government soon turned its attention to the possibility of remodelling the waterways. In the $1920 \mathrm{~s}$, Lenin's formula of "Communism =Soviet rule plus electrification of the whole country" initiated a great drive to construct hydroelectric stations. Even during the Revolutionary war, the possibility of building a Volga-Don canal was so widely discussed that it became the subject of black humour between Stalin and Voroshilov: such major engineering projects, it was felt, would not only be a spectacular achievement for Soviet engineering, with all the attendant publicity at home and abroad; the motif of religion which had frustrated Peter now reappeared in inverted form. The idea was that intervention to "correct a fault" of nature would be a valuable contribution to the atheist re-education campaign because the haphazard and "badly organised" geography which Soviet engineers sought to rectify clearly could not be the work of an intelligent Creator.

It is difficult to establish precisely when the idea of constructing canals for river diversion first arose. The aura surrounding the concept even now is redolent of the atmosphere of the early days of Soviet rule. By the 1950s it had become a desideratum: in one collection of essays on the future of Soviet science published in 1959, it is referred to almost casually in comparison with more modern and daring proposals like the damming of the Bering Straits or the diversion of the North Pacific currents. But the idea of river diversion, couched always in terms of the future, acquired over the years something of a millenial character comparable in a sense to the final achievement of full Communism rather than something likely to be accomplished within the next few Five-Year Plans.

\section{Emphasising the practical}

The new resolution, however, although concerned largely with preliminary work, re-emphasises the practical nature of the project and implies that during the current Five-Year Plan considerable efforts and resources will be devoted to feasibility studies and to surveys and comparison of alternative routes. The "classic" rivers proposed for such diversion are the Ob' and Enisei. According to plans outlined at the International Geographical Congress in Moscow last August a system of reservoirs, pumping stations, canals and tunnels would be built through the Tungai corridor, a depression several hundred kilometers in length. The most promising plan (K. V. Dolgopolov and E. F. Fedorova, Voda-Natsional'noe Dostoyanie, Moscow, 1973) envisages a canal from the confluence of two tributaries of the Ob', the Irtysh and Tobol, which meet at Tobol'sk, to
Atrek, close to the Iranian frontiera distance of some $2300 \mathrm{~km}$. This would allow up to $50 \mathrm{~km}^{3}$ of water to be directed southwards annually.

The main engineering problem would be posed in crossing the SiberianAsian watershed, which would involve pumping the water to a height of some $75 \mathrm{~m}$. The cost of the pumping would be considerably reduced by allowing the water to drive hydroelectric turbines on its downward gradient. An announcement at the Moscow Geographical Congress indicates that the canals are also to be of navigable depth, which would favour the ultimate cost-effectiveness of the project. Several giant reservoirs (colloquially called "seas") with areas up to $100 \mathrm{~km}^{2}$ would be constructed along the $\mathrm{Ob}$ ', Irtysh, and Tobol rivers to store the water before transmission.

A number of variants of the plan have been worked out. The canal itself could be continued through to Khanty-Mansiisk at the confluence of the Irtysh and Ob', or else (as Dolgopolov and Fedorova show it), water from the Ob' could be forced back up the Irtysh to Tobol'sk by a series of pumping stations. The headwaters of the Ob' and Irtysh are to be joined by a canal already under construction. A sidebranch of the Tobol'sk-Atrek canal could be taken westward over the Urals to feed the Ural river which has insufficient water for the massive irrigation projects planned for its lower reaches.

Such plans have caused considerable outcry among conservationists throughout the world, who fear that a diminution of the inflow into the Arctic Ocean might cause massive environmental changes and even result in a southward spread of the polar icecap. To ecologists not of the doomwatch persuasion, however, such an outcome seems unlikely. The hydography of the Ob' basin has been extensively studied. The average annual discharge of the Ob' at Khanty-Mansiisk is some $233 \mathrm{~km}^{3}$, almost five times the proposed uptake of the canal. At Salekhard, where the river flows into the $\mathrm{Ob}^{\text {' }}$ gulf, the annual discharge is $400 \mathrm{~km}^{3}$. The Ob' basin already has a highly developed economy, including the inland port and industrial complex of Novosibirsk and the vast gas and oil fields of Tyumen', Urengoi and Samotlor. Hydroelectricity from the lower $\mathrm{Ob}^{\prime}$ is a fundamental factor in the planned development of these deposits. The $\mathrm{Ob}^{\prime}$ and its tributaries are, moreover, important fish producers.

As even the plans for the lower $\mathrm{Ob}^{\prime}$ hydroelectric station were preceded by a detailed survey of the microclimate of 
the area, and as the exploitation of the Arctic coast of Siberia is also an important feature of Soviet planning, it would seem highly unlikely that the effect of such proposed diversions would not be investigated as fully as possible. According to the Novosti agency, southward redistribution of water from the Irtysh and $\mathrm{Ob}^{\prime}$ (some $75 \mathrm{~km}^{3}$ when all the canals are operational) "would not cause the slightest damage to Siberia". In view of the stress on possible environmental effects written into the resolution this statement may seem somewhat premature, but the emphasis on ecological hazards is significant.

\section{Constructing the canals}

Less concern abroad has been evoked by the methods to be used in constructing the canals. Early "spectaculars" of Soviet hydroengineering such as the White Sea Canal were excavated largely by shovel-power and a labour force of "socially undesirable elements" undergoing re-education, but the new canals can command a higher technology-in particular, nuclear explosions. Indeed, such explosions have already been used on another river-diversion scheme west of the Urals which will bring water from the Pechora south to the Kama and thence to the Volga and the Caspian Sea. According to one of the few press articles dealing with this project (it appeared in Krasnaya Zvezda, the Red Army newspaper, in 1970), the first stage of canal should be operational by the end of the decade and, with its "cascade" of hydroelectric stations, should recoup all costs within four years.

In view of the fact that, according to Moscow Radio, work on the main canal and reservoirs of the $\mathrm{Ob}^{\prime}$ scheme will not commence until the 1990s, it is interesting that the chief surveyor of the Pechora project, Viktor A. Chistyakov, who had previously worked on the Irtysh-Karaganda canal and the Middle-Enisei hydroelectric station, considered that the terrain of the Pechora project was incomparably more difficult. It is the Pechora diversion which nevertheless seems to have the priority.

The use of nuclear explosives is a feature of the Pechora diggings. The criterion for choosing nuclear rather than conventional blasting is primarily cost-effectiveness; a nuclear charge is more efficient when an explosion of more than a few kilotonnes is required. The Soviet Union has shown an active interest in peaceful nuclear explosions (PNEs) since 1960, when she suggested that a thermonuclear explosion might be used to obtain fresh water from glaciers (the suggestion was not implemented). By using a method of deepdrilling and subsequent collapse, radio-

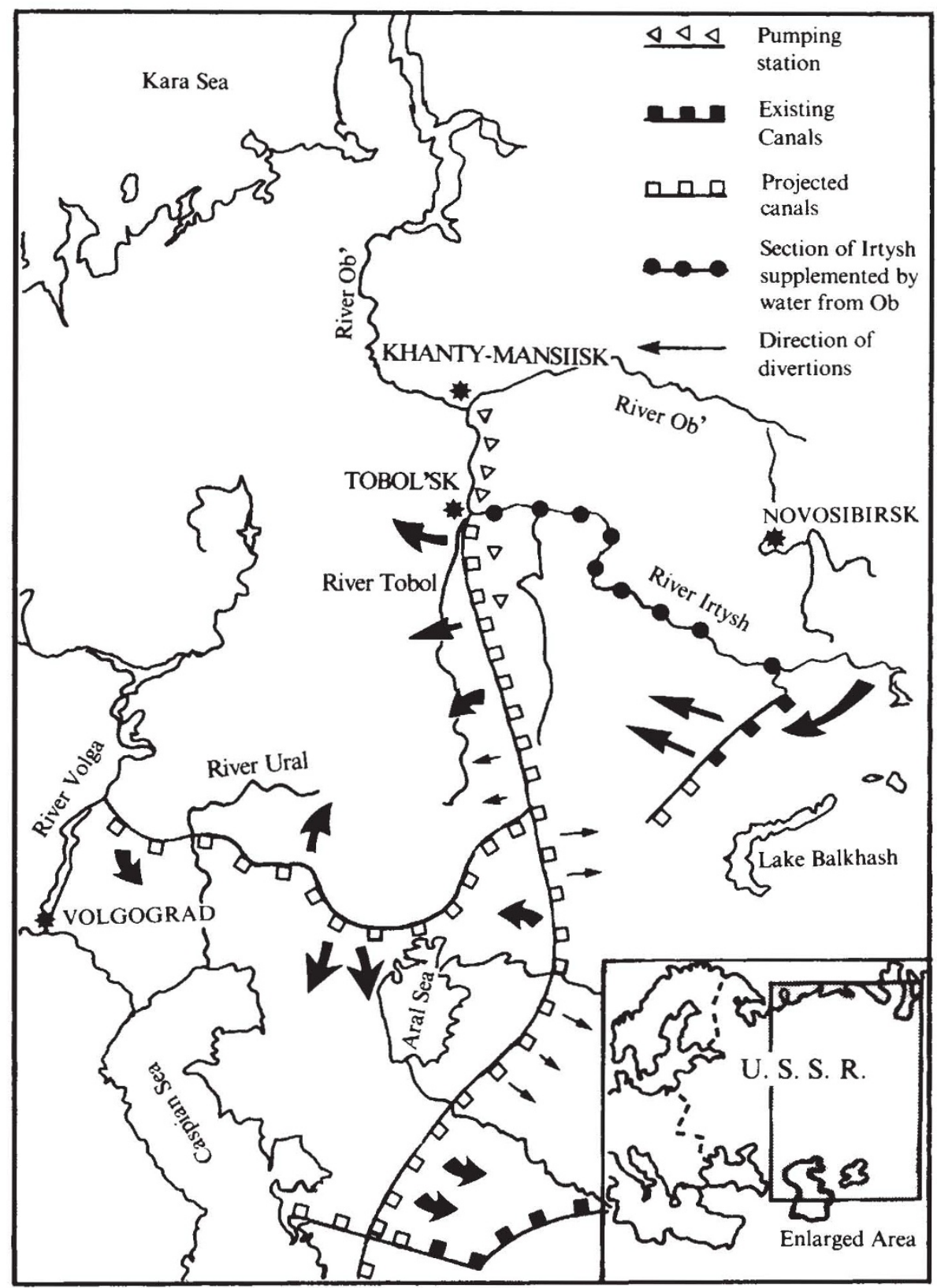

active products can be confined far below the actual installations, so that there seems to be no great safetyhazard; indeed, a film of an early PNE which formed a crater to be used as a reservoir included shots of a man swimming in the crater only a few days after the blast. (No information was ever released about his subsequent history).

Unlike the United States, which is interested in PNEs principally as a means of gas stimulation and envisages no major construction projects that could possibly employ PNEs, the Soviet Union has in its river-diversion schemes a field where they might play a useful role. It is not surprising, therefore, that the Soviet Union is very interested in the conclusion of a threshold treaty which would define the size and amount of charges to be fired and the conditions under which they may be employed. The proposed treaty, now awaiting ratification by the US Senate, suggests a maximum charge of 150 kilotonnes, a size which is easy to verify seismologically and which could not be contest. If more than one maximum blast is to be used in a single row-charge, a maximum of 1.5 megatonnes is proposed for the row; on-site inspection by the other contracting party would be permitted and, furthermore, that party would be permitted to have monitoring instruments down each borehole to measure the yield. This is the first time that the Soviet Union has expressed a willingness to permit on-site inspection, and may well be an indication of how vital the new canals are to the future Soviet economy. Perhaps the new treaty, with all its political implications, may prove no less a benefit to the canal scheme than the immediate practical gains of irrigation and hydroelectric power. fused with any unauthorised weapon 